\title{
Effect of iron folic acid in combination with or without acsorbic acid on hematological and biochemical parameters in pregnant women
}

\author{
Priyanka Sharma, Aachu Agrawal*, Ranjana Nagar
}

Department of Home Scienece, University of Rajasthan, Jaipur, Rajasthan, India

Received: 03 June 2016

Accepted: 01 July 2016

\section{*Correspondence:}

Dr. Aachu Agrawal,

E-mail: aachuagrawal@gmailcom

Copyright: () the author(s), publisher and licensee Medip Academy. This is an open-access article distributed under the terms of the Creative Commons Attribution Non-Commercial License, which permits unrestricted non-commercial use, distribution, and reproduction in any medium, provided the original work is properly cited.

\section{ABSTRACT}

Background: Iron deficiency anemia is major public health problem especially in pregnant women. Addition of Ascorbic acid may improve the effects of iron folic acid supplementation. The present study aimed at assessing the effect of supplementation of iron folic acid with and without ascorbic acid on hematological parameters of pregnant women.

Methods: This case-control study was conducted at Mahila Chikitsalaya, SMS Medical College Hospital, Jaipur. Two hundred pregnant women in the age group of 18-40 years were selected and divided into control $(n=100)$ and experimental group $(n=100)$ randomly. General profile of the subjects was elicited using a pre coded pre tested questionnaire. Women in control group were supplemented with Iron Folic Acid (IFA) and experimental group with IFA+Vitamin C 500mg (Ceilen tablet) for two months. Hematological and biochemical parameters were analyzed at baseline and after the supplementation period of two months.

Results: Average age of the subjects in control and experimental groups was $24.18 \pm 3.77$ and $23.23 \pm 2.96$ years respectively. Post intervention change in experimental Vs Control group was observed-Hb 18.04\% Vs 5.49\%, HCT $3.90 \%$ Vs $1.89 \%$, MCV $1.97 \%$ Vs $0.88 \%$, MCH $6.56 \%$ Vs $1.85 \%$, RBC 5.39\% Vs 3.68\%, Trasnferrin Saturation $12.44 \%$ Vs $7.0 \%$, Serum Iron $6.92 \%$ Vs $2.70 \%$ and TIBC $-4.84 \%$ Vs $3.67 \%$ respectively.

Conclusions: Subjects in experimental group showed significantly higher change in hematological parameters compared to control group.

Keywords: Pregnant women, Iron folic acid, Ascorbic acid, Supplementation

\section{INTRODUCTION}

Anaemia in pregnancy is a major health problem in many developing countries including India. ${ }^{1}$ Iron deficiency is the most common cause of anaemia in pregnancy worldwide and associated with increased risk of preterm births and low birth weight infants. ${ }^{2-5}$ Iron deficiency anaemia is defined as anaemia accompanied by depleted iron stores and signs of compromised supply of iron to the tissues. ${ }^{6}$ Iron absorption increases with increasing length of gestation. The increase is most pronounced after 20 weeks gestation. $^{7}$ Iron status is influenced both by the iron content in the diet as well as bioavailability of dietary iron. Dietary iron intake is proportional with energy intake. The majority of fertile women take dietary iron which is inadequate to fulfill the demands in the second and third trimester. ${ }^{8}$ Iron absorption is also inhibited by calcium of milk and milk products, polyphenols of coffee, tea, and oxalic acid found in vegetables (Spinach). ${ }^{9}$

The bioavailability of iron is low in predominantly cereal based diets because of their high phytate content present in whole grains. The deficiency is prevalent throughout the world because of inefficient absorption of non heme iron which forms the bulk of the iron in the diet. It has been suggested that the bioavailability of iron may be significantly improved by vitamin $\mathrm{C}$ supplementation. 
Ascorbic acid can double iron absorption when taken with a meal. ${ }^{10,11}$

Though the supplementation of IFA remains the cornerstone in treatment and prevention of anaemia, addition of vitamin $\mathrm{C}$ has its other added advantages. Vitamin $\mathrm{C}$ reverses the effect of dietary inhibitors and is one of the most powerful known promoters of non heme iron absorption. ${ }^{12}$

In the view of the above fact, the present study was carried out to ascertain the impact of IFA alone and with vitamin $\mathrm{C}$ supplements on haematological and biochemical parameters of pregnant women in the age group of 18-40 years.

\section{METHODS}

The present study was conducted at Government Mahila Chikitsalaya Jaipur during the period of September 2011 to January 2012. Pregnant women, in the age group of 18-40 years who visited the hospital for the first antenatal check-up (ANC) were approached and those who expressed their willingness to participate were enrolled in the present study. A total of 200 pregnant women were enrolled in the study following purposive sampling. Prior to the commencement of data collection the purpose of the study was explained to all eligible pregnant women and written consent was taken from each subject. Ethical approval for the study was obtained from ethical committee of SMS Medical College, Jaipur. Out of the 200 pregnant women, two study groups were constituted randomly containing 100 subjects in each group. One group served as control group and another group as experimental group. The control group was supplemented with Iron Folic Acid tablets (100 mg elemental iron and $0.5 \mathrm{mg}$ folic acid) and experimental group was supplemented with Iron Folic Acid tablets (100 mg elemental iron and $0.5 \mathrm{mg}$ folic acid) plus $500 \mathrm{mg}$ Vitamin-C tablets (Ceilen tablet). The period of the intervention was for two months. Deworming tablets (albendozole $400 \mathrm{mg}$ ) were given initially at baseline, before proceeding for the supplementation to ensure the efficacy of iron and folic acid (with and without Vitamin C) absorption.

Blood samples were collected for assessment of haematological and biochemical parameters before and at the end of the supplementation by a trained technician. All the tests were repeated in the same biochemical \& pathology laboratory by same technicians.

\section{Haematological and biochemical estimations}

Blood sample collection: The blood samples were withdrawn from the antecubital vein by means of sterile plastic vacutainer syringes. About $7 \mathrm{ml}$ of blood was collected into two vacutain tubes; about $2 \mathrm{ml}$ of blood was collected in EDTA (ethylenediamine tetraacetic acid) containing tube, and remaining quantity of blood was left in a plain non-anticoagulant tube without separator to obtain the serum samples.

To assess the impact of supplementation of IFA with and without Vitamin C, Complete blood count (CBC), Serum iron, Total iron binding capacity (TIBC), Ferritin, Transferrin Saturation (TS) and serum Vitamin C levels were determined. Complete blood count was determined through a Coulter Trivitron; Serum iron was determined by iron-ferrozine spectrophotometric method of Stookey, Itano and Artiss et al by using Biosystems Kit, Spain.

Total Iron Binding Capacity (TIBC) and transferrin saturation was calculated from the ratio of serum iron concentration to total iron binding capacity. ${ }^{13-17}$ Serum Ferritin was estimated by fully automated bi-directionally interfaced chemiluminescent Immunoassay (CLIA) technique. Estimation of Vitamin C levels in plasma was done by using the modified method of 2,6dichlorophenolindophenol dye titration method of Varley. ${ }^{18}$

\section{Statistical analysis}

Baseline iron and anemia status of pregnant women were compared between control and treatment groups. Mean relative difference in $\mathrm{Hb}, \mathrm{RBC}$, Serum iron, Total iron binding capacity (TIBC), Transferrin Saturation (TS) and serum Vitamin C were compared from baseline to followup in both the groups.

Cut-off levels for haematological and biochemical parameters, $\mathrm{Hb}<11 \mathrm{~g} / \mathrm{dl}$, serum ferritin $<12 \mu \mathrm{g} / \mathrm{L}$, Hct $<$ $32 \%, \mathrm{MCV}<80 \mathrm{fl}, \mathrm{MCH}<30 \mathrm{pg} / \mathrm{L}, \mathrm{MCHC}<30, \mathrm{RBC}<$ $4.1 \mathrm{million} / \mathrm{mm}^{3}$, transferrin saturation $<15 \%$, serum iron $<50 \mu \mathrm{g} / \mathrm{dl}$ and TIBC $>410$ were considered as being low and indicative of iron deficiency. ${ }^{6,19-24}$

Hemoglobin level >11.0 gm/dl was considered as normal, $\mathrm{Hb}$ between $10.11 \mathrm{~g} / \mathrm{dl}$ was considered as mild anemia, $\mathrm{Hb}$ between 7-10 $\mathrm{g} / \mathrm{dl}$ was considered as moderate anemia and $\mathrm{Hb}<7 \mathrm{~g} / \mathrm{dl}$ was defined as severe anemia. Iron-deficiency anemia in subjects was also determined using hemoglobin and serum ferritin levels. Subjects were categorized as normal if the $\mathrm{Hb} \geq 11 \mathrm{~g} / \mathrm{dl}$ and serum ferritin $>12 \mathrm{micg} / \mathrm{L}$, Iron depletion stage if $\mathrm{Hb} \geq 11 \mathrm{~g} / \mathrm{dl}$ and $\mathrm{SF}<12 \mathrm{micg} / \mathrm{L}$, Iron deficiency anaemia stage if $\mathrm{Hb}<$ $11 \mathrm{~g} / \mathrm{dl}$ and $\mathrm{SF}<12 \mathrm{micg} / \mathrm{L}$ and anaemia not due to iron deficiency if $\mathrm{Hb}<11 \mathrm{~g} / \mathrm{dl}$ and $\mathrm{SF}>12 \mathrm{micg} / \mathrm{L}$.

The data collected was tabulated and analyzed. Frequencies and percentage were calculated and wherever applicable, mean \pm SD was assessed. Changes in mean levels of different hematological and biochemical parameters were assessed using paired t-test and p-value $<0.05$ was considered as significant. 


\section{RESULTS}

At the time of registration 100 subjects were enrolled in the study in both the groups but 16 subjects in control and 14 subjects in experimental group dropped out from the study till follow up.

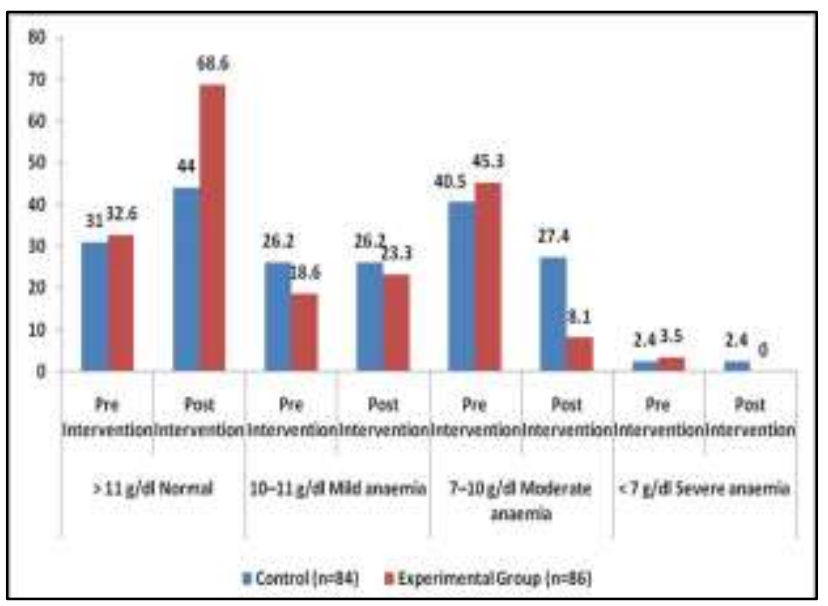

Figure 1: Changes in haemoglobin levels of subjects in control and experimental group.

As shown in table-I, average age of the subjects in control and experimental groups was 24.18 \pm 3.77 years and $23.23 \pm 2.96$ years respectively. Maximum subjects were in the age group of 20-25 years in both the groups. Almost all the subjects were housewives. Average monthly income in control and experimental groups was Rs. $4792.93 \pm 2354.99$ and Rs. $6555.00 \pm 2819.39$.

Majority of the subjects in control group (78.8\%) had monthly income below Rs.5,000/- per month. In experimental group $41 \%$ subjects had monthly income below Rs. 5000/- while 52\% subjects had their monthly income between Rs. 5000 to 10,000/-. Maximum subjects were vegetarian in both the groups. Mostly women were in $2^{\text {nd }}$ trimester of pregnacy in both the groups $(70-75 \%)$.

Table 2 presents the mean change in various hematological and biochemical parameters among control and experimental groups. In control group, the mean MCHC level at baseline was $33.10 \mathrm{~g} / \mathrm{dl}$ but after the supplementation of IFA for two months the post MCHC level became $33.65 \mathrm{~g} / \mathrm{dl}$. There was a relative change of $1.79 \%$ which was statistically significant $(\mathrm{p}<0.01)$.

In experimental group, mean $\mathrm{MCHC}$ value at baseline was $32.92 \mathrm{~g} / \mathrm{dl}$ and after supplementation of IFA+500 mg vitamin $\mathrm{C}$ the mean level of $\mathrm{MCHC}$ raised to $33.80 \mathrm{~g} / \mathrm{dl}$. A significant relative change of about $4.06 \%$ was observed after supplementation $(\mathrm{p}<0.01)$ in experimental group.
Mean Hemoglobin level in control group was $10.26 \mathrm{~g} / \mathrm{dl}$ at baseline and $10.79 \mathrm{~g} / \mathrm{dl}$ after supplementation. The relative change was $5.49 \% \quad(\mathrm{p}<0.01)$. In experimental group, mean $\mathrm{Hb}$ level was $10.20 \mathrm{~g} / \mathrm{dl}$ at baseline while the post supplementation level was $11.88 \mathrm{~g} / \mathrm{dl}$. Relative change was $18.04 \%$ in experimental group $(\mathrm{p}<0.01)$ after supplementation.

At baseline mean Hematocrit level (Hct) in control group was $31.11 \%$ and at post intervention $31.03 \%$. Relative change of $1.89 \%$ was observed after supplementation which was not statistically significant. In experimental group, mean Hct level at baseline was $30.66 \%$ which increased to $31.43 \%$ after supplementation.

A relative change of $3.90 \%$ was observed in Hct in experimental group which was statistically significant $(\mathrm{p}$ $<0.01)$.

Table 1: General information of subjects in control and experimental groups.

\begin{tabular}{|c|c|c|}
\hline Age group & Control group & $\begin{array}{l}\text { Experimental } \\
\text { group }\end{array}$ \\
\hline$<20$ year & $16(16)$ & $21(21)$ \\
\hline 20-25 Year & $54(54)$ & $60(60)$ \\
\hline$>25$ Year & $30(30)$ & $19(19)$ \\
\hline Mean \pm SD & $24.18 \pm 3.77$ & $23.23 \pm 2.96$ \\
\hline \multicolumn{3}{|c|}{ Occupation of husband } \\
\hline Business & $7(7)$ & $14(14)$ \\
\hline Service & $19(19)$ & $22(22)$ \\
\hline Semi-unskilled & $56(56)$ & $47(47)$ \\
\hline Skilled & $17(17)$ & $17(17)$ \\
\hline Other & $1(1 \%)$ & - \\
\hline \multicolumn{3}{|c|}{ Occupation of the subjects } \\
\hline Working & - & $1(1.0)$ \\
\hline Housewife & $100(100.0)$ & $99(99.0)$ \\
\hline \multicolumn{3}{|c|}{ Income categories } \\
\hline Rs. $<5000$ & $78(78.8)$ & $41(41.0)$ \\
\hline $\begin{array}{l}\text { Rs. 5001- } \\
10,000\end{array}$ & $20(19.2)$ & $52(52.0)$ \\
\hline Rs. $>10,001$ & $2(2.0)$ & $7(7.0)$ \\
\hline $\begin{array}{l}\text { Mean Income } \\
\text { (Rs.) }\end{array}$ & $4792.93 \pm 2354.99$ & $6555.00 \pm 2819.39$ \\
\hline \multicolumn{3}{|l|}{ Food habit } \\
\hline Vegetarian & $61(61)$ & $66(66)$ \\
\hline Non-vegetarian & $37(37)$ & $31(31)$ \\
\hline Eggetarian & $2(2)$ & $3(3.0)$ \\
\hline \multicolumn{3}{|l|}{ Trimester } \\
\hline $1^{\text {st }}$ Trimester & $1(1)$ & $2(2)$ \\
\hline $2^{\text {nd }}$ Trimester & $75(75)$ & $70(70)$ \\
\hline $3^{\text {rd }}$ Trimester & $24(24)$ & $28(28)$ \\
\hline
\end{tabular}


Table 2: Haematological and biochemical parameters of the subjects at baseline and post supplementation.

\begin{tabular}{|c|c|c|c|c|c|}
\hline \multirow[t]{2}{*}{ Parameters } & & \multicolumn{2}{|c|}{ Control } & \multicolumn{2}{|c|}{ Experimental group } \\
\hline & & Mean & Std. Deviation & Mean & Std. Deviation \\
\hline \multirow[t]{5}{*}{$\mathrm{MCHC}(\mathrm{g} / \mathrm{dl})$} & Pre & 33.10 & 2.39 & 32.92 & 2.14 \\
\hline & Post & 33.65 & 2.33 & 33.80 & 2.00 \\
\hline & Change & 0.56 & 0.83 & 0.88 & 0.77 \\
\hline & $\%$ Change & 1.79 & 2.03 & 4.06 & 3.17 \\
\hline & t-test (p-value) & \multicolumn{2}{|c|}{$-6.090(0.000)^{* * *}$} & \multicolumn{2}{|c|}{$10.605(0.000)^{* *}$} \\
\hline \multirow[t]{5}{*}{$\mathrm{Hb}(\mathrm{g} / \mathrm{dl})$} & Pre & 10.26 & 1.56 & 10.20 & 1.67 \\
\hline & Post & 10.79 & 1.52 & 11.88 & 1.38 \\
\hline & Change & 0.53 & 0.38 & 1.68 & 0.49 \\
\hline & $\%$ Change & 5.49 & 4.44 & 18.04 & 7.03 \\
\hline & t-test (p-value) & \multicolumn{2}{|c|}{$-12.742(0.000)^{* *}$} & \multicolumn{2}{|c|}{$31.930(0.000)^{* *}$} \\
\hline \multirow[t]{5}{*}{$\operatorname{HCT}(\%)$} & Pre & 31.11 & 7.09 & 30.66 & 4.50 \\
\hline & Post & 31.03 & 4.33 & 31.43 & 5.14 \\
\hline & Change & -0.08 & 5.63 & 0.77 & 2.42 \\
\hline & $\%$ Change & 1.89 & 5.37 & 3.90 & 3.28 \\
\hline & t-test (p-value) & \multicolumn{2}{|c|}{$0.126(0.900) \mathrm{NS}$} & \multicolumn{2}{|c|}{$-2.920(0.004)^{* *}$} \\
\hline \multirow[t]{5}{*}{$\operatorname{MCV}(f l)$} & Pre & 83.11 & 7.67 & 80.04 & 9.25 \\
\hline & Post & 84.12 & 7.34 & 80.74 & 10.27 \\
\hline & Change & 1.01 & 2.87 & 0.70 & 9.81 \\
\hline & $\%$ Change & 0.88 & 1.49 & 1.97 & 1.99 \\
\hline & t-test (p-value) & \multicolumn{2}{|c|}{$-3.224(0.002)^{* *}$} & \multicolumn{2}{|c|}{$0.312(0.756) \mathrm{NS}$} \\
\hline \multirow[t]{5}{*}{$\mathrm{MCH}(\mathrm{pg})$} & Pre & 28.01 & 3.48 & 26.44 & 3.90 \\
\hline & Post & 28.22 & 4.43 & 27.30 & 3.92 \\
\hline & Change & -0.21 & 2.74 & 0.84 & 0.76 \\
\hline & $\%$ Change & 1.85 & 3.25 & 6.56 & 5.42 \\
\hline & t-test (p-value) & \multicolumn{2}{|c|}{$-0684(0.496) \mathrm{NS}$} & \multicolumn{2}{|c|}{$10.148(0.000)^{* *}$} \\
\hline & Pre & 3.66 & 0.56 & 3.77 & 0.42 \\
\hline$\left(\times 10^{6} / \mu 1\right)$ & Post & 3.79 & 0.55 & 3.97 & 0.44 \\
\hline & Change & 0.13 & 0.17 & 0.20 & 0.19 \\
\hline & $\%$ Change & 3.68 & 5.34 & 5.39 & 5.35 \\
\hline & t-test (p-value) & $6.901(0$ & & 9.847( & \\
\hline Trans Sat $(\%)$ & Pre & 17.31 & 11.54 & 16.46 & 9.98 \\
\hline & Post & 17.71 & 11.89 & 18.34 & 10.83 \\
\hline & Change & 0.40 & 5.41 & 1.88 & 1.40 \\
\hline & $\%$ Change & 7.00 & 7.54 & 12.44 & 7.31 \\
\hline & t-test (p-value) & $0.689(0$ & & 12.454 & \\
\hline S. Iron $(\mu \mathrm{g} / \mathrm{dl})$ & Pre & 63.12 & 41.05 & 66.43 & 39.70 \\
\hline & Post & 62.98 & 41.04 & 70.13 & 39.99 \\
\hline & Change & -0.14 & 15.52 & 3.7 & 2.64 \\
\hline & $\%$ Change & 2.70 & 2.73 & 6.92 & 6.67 \\
\hline & t-test (p-value) & $0.086(0$ & & 13.013 & \\
\hline Ferritin (ng/ml) & Pre & 27.23 & 23.73 & 41.24 & 68.62 \\
\hline & Post & 27.75 & 21.42 & 43.35 & 70.46 \\
\hline & Change & 0.52 & 17.83 & 2.11 & 4.53 \\
\hline & $\%$ Change & 10.26 & 27.37 & 10.32 & 18.03 \\
\hline & t-test (p-value) & $0.266(0$ & & 4.329( & \\
\hline TIBC $(\mu \mathrm{g} / \mathrm{dl})$ & Pre & 391.74 & 90.44 & 427.74 & 92.51 \\
\hline & Post & 382.23 & 85.41 & 407.94 & 92.93 \\
\hline & Change & -9.51 & 34.70 & -19.80 & 9.61 \\
\hline & $\%$ Change & -3.67 & 5.76 & -4.84 & .2 .51 \\
\hline & t-test (p-value) & -2.512 & & -19.110 & \\
\hline Serum Vitamin-C & Pre & 0.41 & 0.18 & 0.41 & 0.81 \\
\hline$(\mathrm{mg} / \mathrm{dl})$ & Post & 0.44 & 0.16 & 0.57 & 0.17 \\
\hline & Change & 0.03 & 0.08 & 0.16 & 0.06 \\
\hline & $\%$ Change & 14.06 & 30.15 & 53.07 & 46.67 \\
\hline
\end{tabular}


Table 3: Distribution of subjects with respect to cut off values of parameters in control and experimental groups.

\begin{tabular}{|c|c|c|c|}
\hline Parameters & & $\begin{array}{l}\text { Control Group } \\
(\mathrm{n}=\mathbf{8 4})\end{array}$ & Experimental Group ( $n=86)$ \\
\hline \multirow{4}{*}{$\mathrm{HCT}<32 \%$} & Pre Intervention & $53(63.1)$ & $50(58.1)$ \\
\hline & Post Intervention & $46(54.8)$ & $41(47.7)$ \\
\hline & $\%$ Change & 8.3 & 10.4 \\
\hline & $\mathrm{p}$ value & $0.016^{*}$ & $0.004 *$ \\
\hline \multirow[t]{4}{*}{$\mathrm{MCV}<80 \mathrm{fl}$} & Pre Intervention & $23(27.4)$ & $34(39.5)$ \\
\hline & Post Intervention & $21(25.0)$ & $29(33.7)$ \\
\hline & $\%$ Change & 2.4 & 5.8 \\
\hline & $\mathrm{p}$ value & $0.625 \mathrm{NS}$ & $0.062 \mathrm{NS}$ \\
\hline \multirow{4}{*}{$\mathrm{MCH}<30 \mathrm{pg}$} & Pre Intervention & $62(73.8)$ & $74(86.0)$ \\
\hline & Post Intervention & $54(64.3)$ & $63(73.3)$ \\
\hline & $\%$ Change & 9.5 & 12.7 \\
\hline & $\mathrm{p}$ value & $0.21 *$ & $0.001 *$ \\
\hline \multirow[t]{4}{*}{$\mathrm{MCHC}<30 \mathrm{~g} / \mathrm{dl}$} & Pre Intervention & $10(11.9)$ & $8(9.3)$ \\
\hline & Post Intervention & $5(6.0)$ & $1(1.2)$ \\
\hline & $\%$ Change & 5.9 & 8.1 \\
\hline & $\mathrm{p}$ value & $0.062 \mathrm{NS}$ & $0.016^{*}$ \\
\hline \multirow{4}{*}{$\mathrm{RBC}<4.1\left(\times 10^{6} / \mu \mathrm{l}\right)$} & Pre Intervention & $68(81.0)$ & $65(75.6)$ \\
\hline & Post Intervention & 61 (72.6) & $44(51.2)$ \\
\hline & $\%$ Change & 8.4 & 24.4 \\
\hline & $\mathrm{p}$ value & $0.039^{*}$ & $0.000 *$ \\
\hline \multirow{4}{*}{ Serum Ferritin $<12 \mathrm{ng} / \mathrm{ml}$} & Pre Intervention & $20(23.8)$ & 27 (31.4) \\
\hline & Post Intervention & 19 (22.6) & $21(24.4)$ \\
\hline & $\%$ Change & 1.2 & 7.0 \\
\hline & $\mathrm{p}$ value & $1.00 \mathrm{NS}$ & $0.031 *$ \\
\hline \multirow[t]{4}{*}{ TIBC $>410 \mu \mathrm{g} / \mathrm{dl}$} & Pre Intervention & $41(48.8)$ & $43(50.0)$ \\
\hline & Post Intervention & $31(36.9)$ & $39(45.3)$ \\
\hline & $\%$ Change & -11.9 & -4.7 \\
\hline & $\mathrm{p}$ value & $0.002^{* *}$ & $0.125 \mathrm{NS}$ \\
\hline \multirow{4}{*}{$\begin{array}{l}\text { Transferrin Saturation } \\
<15 \%\end{array}$} & Pre Intervention & $58(69.0)$ & $65(75.6)$ \\
\hline & Post Intervention & $55(65.5)$ & $53(61.6)$ \\
\hline & $\%$ Change & -3.5 & -14 \\
\hline & $\mathrm{p}$ value & $0.250 \mathrm{NS}$ & $0.000 * *$ \\
\hline \multirow{4}{*}{$\begin{array}{l}\text { Serum Iron } \\
<50 \mu \mathrm{g} / \mathrm{dl}\end{array}$} & Pre Intervention & $42(50.0)$ & $40(46.5)$ \\
\hline & Post Intervention & $41(48.8)$ & $37(43.0)$ \\
\hline & $\%$ Change & 1.2 & 3.5 \\
\hline & $\mathrm{p}$ value & $1.00 \mathrm{NS}$ & $0.250 \mathrm{NS}$ \\
\hline
\end{tabular}

** Significant at $\mathrm{p}<0.01, *$ Significant at $\mathrm{p}<0.05, \mathrm{NS}=$ Non-significant. The values given in the parenthesis are in terms of percentage.

Mean MCV value at baseline was $83.11 \mathrm{fl}$ in control group and $80.04 \mathrm{fl}$ in experimental group. After supplementation, mean MCV levels raised to $84.12 \mathrm{fl}$ and $80.74 \mathrm{fl}$ in control and experimental group respectively. A relative change of $0.88 \%$ and $1.97 \%$ was observed in control and experimental groups respectively $(\mathrm{p}<0.01)$.

Average Mean Corpuscular Haemoglobin (MCH) in control and supplemented group was $28.01 \mathrm{pg}$ and 26.44 pg respectively while mean $\mathrm{MCH}$ values after supplementation in these groups was $28.22 \mathrm{pg}$ and 27.30 pg respectively.
Relative change was higher in supplemented group $(6.56 \%)$ compared to control group $(1.85 \%)(\mathrm{p}<0.01)$. In control group, mean RBC level was $3.66 \times 10^{6} / \mu 1$ and $3.79 \times 10^{6} / \mu \mathrm{l}$ at baseline and post supplementation respectively.

In experimental group, the mean level of RBC at baseline and post supplementation was 3.77 and $3.97 \times 10^{6} / \mu 1$ respectively. Relative change in control and experimental groups was $3.68 \%$ and $5.39 \%$ respectively $(\mathrm{p}<0.01)$. 
Table 4: Distribution of the subjects as per anaemia status on the basis of $\mathrm{HB}$ and ferritin.

\begin{tabular}{|c|c|c|c|}
\hline & & $\begin{array}{l}\text { Control } \\
(n=84)\end{array}$ & $\begin{array}{l}\text { Experimental } \\
\text { group } \\
(\mathbf{n}=\mathbf{8 6})\end{array}$ \\
\hline \multirow{2}{*}{$\begin{array}{l}\text { Normal stage } \\
(\mathrm{Hb} \geq 11 \mathrm{~g} / \mathrm{dl} \text { and } \\
\mathrm{SF}>12 \mathrm{micg} / \mathrm{L})\end{array}$} & Pre & $23(27.4)$ & $24(27.9)$ \\
\hline & Post & $33(39.3)$ & $54(62.8)$ \\
\hline \multirow{2}{*}{$\begin{array}{l}\text { Iron depletion stage } \\
(\mathrm{Hb} \geq 11 \mathrm{~g} / \mathrm{dl} \text { and } \\
\mathrm{SF}<12 \mathrm{micg} / \mathrm{L})\end{array}$} & Pre & $6(7.1)$ & $6(7.0)$ \\
\hline & Post & $8(9.5)$ & $10(11.6)$ \\
\hline \multirow{2}{*}{$\begin{array}{l}\text { Iron deficiency } \\
\text { anaemia stage } \\
(\mathrm{Hb}<11 \mathrm{~g} / \mathrm{dl} \text { and } \\
\mathrm{SF}<12 \mathrm{micg} / \mathrm{L})\end{array}$} & Pre & $14(16.7)$ & $21(24.4)$ \\
\hline & Post & $11(13.1)$ & $11(12.8)$ \\
\hline \multirow{2}{*}{$\begin{array}{l}\text { Anaemia not due to } \\
\text { iron deficiency }(\mathrm{Hb} \\
<11 \mathrm{~g} / \mathrm{dl} \text { and } \mathrm{SF}>12 \\
\mathrm{micg} / \mathrm{L})\end{array}$} & Pre & $41(48.8)$ & $35(40.7)$ \\
\hline & Post & $32(38.1)$ & $11(12.8)$ \\
\hline
\end{tabular}

Transferrin saturation is an indicator of iron stores in the body. In the present study, mean transferrin saturation levels in control group was $17.31 \%$ and $17.71 \%$ at baseline and post supplementation respectively. While in experimental group the mean transferrin saturation at baseline was $16.46 \%$ which raised to $18.34 \%$ after supplementation. Relative change in transferring saturation was higher in experimental group i.e. $12.44 \%$ compared to control group $7.0 \%(\mathrm{p}<0.01)$.

Serum iron level in control group was $63.12 \mu \mathrm{g} / \mathrm{dl}$ at baseline which raised to $62.98 \mu \mathrm{g} / \mathrm{dl}$ after supplementation $(\mathrm{p}>0.05)$. In experimental group, pre and post supplementation serum iron levels were 66.43 and 70.13 $\mu \mathrm{g} / \mathrm{dl}$ respectively $(\mathrm{p}<0.01)$. Relative change in control and experimental group was $2.7 \%$ and $6.92 \%$ respectively.

Total Iron Binding Capacity (TIBC) of control at baseline and post supplementation were 391.74 and $382.29 \mu \mathrm{g} / \mathrm{dl}$ respectively. In experimental group, the mean levels of TIBC at baseline and post supplementation were 427.74 and $407.94 \mu \mathrm{g} / \mathrm{dl}$. Relative change of $-3.67 \%$ and $-4.84 \%$ was observed in TIBC among control and experimental groups.

Serum Vitamin C level in control group at baseline and post supplementation was 0.41 and $0.44 \mathrm{mg} / \mathrm{dl}$ respectively. In experimental group, serum Vitamin-C level was $0.41 \mathrm{mg} / \mathrm{dl}$ at baseline and $0.57 \mathrm{mg} / \mathrm{dl}$ after supplementation. Relative change was $14.06 \%$ in control and $53.07 \%$ in experimental group $(\mathrm{p}<0.01)$.

Table 3 presents the distribution of subjects according to cut-off values of different parameters among control and experimental groups. As shown in the table, at baseline $63.1 \%$ subjects in control group and $58.1 \%$ subjects in experimental group had $\mathrm{HCT}<32 \%$. After intervention a decrease of $8.3 \%$ in control group and $10.4 \%$ in experimental was observed $(\mathrm{p}<0.05)$. Similar change in proportion was found with respect to $\mathrm{MCV}<80 \mathrm{fl}, \mathrm{MCH}$ $<30 \mathrm{pg}$ and $\mathrm{MCHC}<30 \mathrm{~g} / \mathrm{dl}$. A huge difference in the change of proportion of subjects with $\mathrm{RBC}<4.1$ ( $\times$ $10^{6} / \mathrm{g} / \mathrm{dl}$ ) was observed in experimental group compared to control group (8.4\% vs $24.4 \%$ ) after supplementation. Proportion of subjects with Transferrin Saturation < $15 \%$ improved $3.5 \%$ in control group while a change of $14.0 \%$ was observed in experimental group.

Figure 1 presents the change in the proportion of subjects according to their hemoglobin levels. At baseline $26.2 \%$ subjects were mild anemic, $40.5 \%$ subjects were moderate anemic and $2.4 \%$ subjects were severe anemic in control group while in experimental group $18.6 \%$ subjects were mild anemic, $45.3 \%$ subjects were moderate anemic and $3.5 \%$ subjects were severe anemic. After supplementation, experimental group showed better improvement as $68.6 \%$ subjects shifted in the normal category, $8.1 \%$ subjects remained in moderate anemia and no subject left in severe anemia.

Table 4 presents the prevalence of iron deficiency anemia determined through serum ferritin and hemoglobin levels of the subjects. In the control group $27.4 \%$ subjects and in experimental group $27.9 \%$ subjects were normal at baseline. After supplementation, 39.3\% subjects shifted in the normal category while in experimental group $62.8 \%$ subjects came in normal category. Iron deficiency anemia measured through $\mathrm{hb}<11 \mathrm{~g} / \mathrm{dl}$ and $\mathrm{sf}<12 \mu \mathrm{g} / \mathrm{dl}$ was $16.7 \%$ in control and $24.4 \%$ in experimental group at baseline which declined to $13.1 \%$ and $12.8 \%$ in control and experimental group respectively. Change of $2.4 \%$ and $4.6 \%$ in control and experimental group was observed in iron depletion stage $(\mathrm{hb} \geq 11 \mathrm{~g} / \mathrm{dl}$ and $\mathrm{sf}<12$ $\mathrm{g} / \mathrm{dl})$.

\section{DISCUSSION}

It is concluded in the present study that vitamin $\mathrm{C}$ supplementation enhances the effectively of IFA on all haematological and biochemical parameters. A study by Gillispie on anaemic preschool children, consuming a purely vegetarian diet has shown that $100 \mathrm{mg}$ of crystalline ascorbic acid taken as a tablet along with lunch and dinner meals for two months brought about a significant improvement in the haemoglobin level and it was higher than the rise obtained with only iron supplements in the same study $(1.9 \mathrm{~g} / \mathrm{dl}$ vs $1.1 \mathrm{~g} / \mathrm{dl})$. Similar findings were reported by Mehnaz et al. ${ }^{25,26}$

Sharma worked on adolescent girls of poor community and observed that even weekly supplementation of vitamin $\mathrm{C}$ along with iron/folate had a significant higher increase in haemoglobin concentration, as compared to weekly iron/folate supplementation alone. ${ }^{27}$ Joseph and Ramesh reported that the prevalence of anaemia was high in women and a weekly supervised dose of iron, folic acid and vitamin $\mathrm{C}$ effectively tackle the problem and improves work efficiency. ${ }^{28}$ Therefore there is need for 
an increase in ascorbic acid intake to enhance the absorption of iron supplements which is part of routine drug for antenatal women (Shu and Ogboda). ${ }^{29}$

It clears that IFA with supplementation of vitamin $\mathrm{C}$ plays an important role in increasing the $\mathrm{Hb}$ level of pregnant women (Mehnaz et al). ${ }^{26}$

The significant finding of the present study recommends that the pregnant women must take proper nutrition and be supplemented with IFA along with vitamin $\mathrm{C}$. The Government while implementing pregnancy related programmes is already providing IFA but it should also provide vitamin $\mathrm{C}$.

\section{CONCLUSION}

Subjects in experimental group showed significantly higher change in hematological parameters compared to control group.

\section{ACKNOWLEDGEMENTS}

Authors are thankful to the subjects enrolled in the study. Also we are thankful to Biochemistry and Pathology department for supporting throughout the study.

\section{Funding: No funding sources}

Conflict of interest: None declared

Ethical approval: The study was approved by the Institutional Ethics Committee SMS Medical College, Jaipur before commencement of study

\section{REFERENCES}

1. Mahomed K. Iron and Folate Supplementation in pregnancy. Cochrane Database Syst. Rev. 2007;3 CD001135.

2. Quillan JP, Kwong A, Passmore P. An epidemiological investigation of pre-eclampsia and elevated blood pressure among Kampuchean refugee women at Sakaco Holding Center, Thailand. J Trop Med Hyg. 1983;86(5):185-91.

3. Spinillo A, Capuzzo E, Piazzi G, Nicola S, Colonna $\mathrm{L}$ and Iasci A. Maternal high-risk factors and serverity of growth deficit in small for gestational age infants. Early Hum. Dev. 1994;38:35-43.

4. Sapre S, Joshi V. 3 E's for safe motherhood. J Obstet Gyn Fam. Wel. 1996;2:7-11.

5. Cuervo LG, Mahomed K. Treatment for iron deficiency anaemia in pregnancy (Cochrane review). Issue 4 The Cochrane library. Chichester, UK: John Wiley and Sons, Ltd (Level 1). 2003;8(1):92.

6. World Health Organization/United Nations University/UNICEF. Iron deficiency anaemia, assessment, Prevention and Control: a guide for programme managers. Geneva: WHO, 2001.
7. Barrett FR, Whittaker PG, Williams JG. Absorption of non haem iron from food during pregnancy. BMJ. 1994;309:79.

8. FAO/WHO Requirements of vitamin A, iron, folate and vitamin $\mathrm{B}_{12}$. Report of a Joint FAO / WHO Expert Consultation. Rome: FAO (FAO Food and Nutrition Series No. 23). 1988.

9. Baynes RD, Skikine B. Iron absorption: In: Brock, JH, Halliday JW, Pipard MJ, Powell LW (eds). Iron metabolism in Health and Disease, London, UK: WB Saunders. 1994:151-87.

10. World Health Organization, Hook worm infection and Anaemia in girls and women. Report of WHO informal consultation Geneva. WHO, 1994.

11. Schultink WJ, Angeles AI, Sastroamidjojo R, Gross R, Kayadi D. Weekly micronutrient supplementation to build iron stores in female Indonesian adolescents. Am J Clin Nutr. 1997;66(1):177-83.

12. Lynch SR. Ascorbic acid and iron nutrition, ASDCJ Dent Child. 1981;48:61-3.

13. Stookey LL. Ferrozine - a new spectrophotometric reagent for iron Anal chem. 1970;42:779-81.

14. Itano M. Serum Iron Survey. Am J Clin Pathol. 1978;70:516-22.

15. Artiss JD, Vinogradev S, Zak B. Spectrophotometric study of sensitive reagents for serum iron. Clin Biochem. 1981;14:311-5.

16. Tietz textbook of clinical chemistry and molecular diagnostic. $4^{\text {th }}$ ed. Burtis CA, Aswood ER, Bruns DE. WB Saunders Co; 2005.

17. Mazza J. Manual of Clinical Hematology, Philadelphia: Lippincott Williams and Wilkins, 2002:129.

18. Varley's Practical Clinical Bio-Chemistry. 6th ed. Alan H, Gowenlock, CBS Publishers and Distributors Pvt. Ltd. 1988:927.

19. Cook JD, Finch CA. Assessing iron status of a population. Am J Clin Nutr. 1979;32:2115-9.

20. Puolakka, J, Janne O, Pakarinen A, Vihko R. Serum ferritin as a measure of stores during and after normal pregnancy with and without iron supplements. Acta Obstet Gynecol Scand supple. 1980;95:43-51.

21. International Nutritional Anaemia Consultative Group (INAC). Iron deficiency in women. Washington D.C. Nutrition Foundation. 1985;21-36.

22. Chard T, Lilford RJ. How useful is a test? J stud Ed. Progress in Obstetrics and Gynaecology. 1986;6:315.

23. Warren GT. Comparison of tests for diagnosis of iron depletion in pregnancy. American Journal of Obstetrics and Gynaecology. 1988;159 :1132-4.

24. Earl R, Woteki EM. Eds. Iron deficiency anaemia recommended guidelines for the prevention, detection and managements among US children and women of child bearing age. Washington DC. National Academy Press, 1993. 
25. Gillespie S. Malnutrition in South East Asia. A regional profile, Rosa Publication no. 5, UNICEF. Regional office for South Asia Nov. 1997:92-3.

26. Mehnaz S. Afzal S. Khalil S, Khan Z. Impact of iron, folate and vitamin supplementation on the prevalence of Iron Deficiency Anemia in Nonpregnant females of periurban Areas of Aligarh. Indian Journal of community Medicine. 2006;31(3):201-3.

27. Sharma A, Prasad K, Rao VK. Identification of an appropriate strategy of control anaemia in adolescent girl of poor communities. Indian Pediatrics. 2000;37: 261-7.
28. Joseph B and Ramesh N. Weekly dose of iron-folate supplementation with vitamin $\mathrm{c}$ in the work place can prevent anemia in women employees. Pak J Med Sci. 2013;29(1):47-52.

29. Shu EN, Ogbodo SO. Role of ascorbic acid in the prevention of iron deficiency anaemia in pregnancy. Biochemical Research. 2005;16(1):40-4.

Cite this article as: Sharma P, Agrawal A, Nagar R. Effect of iron folic acid in combination with or without acsorbic acid on hematological and biochemical parameters in pregnant women. Int J Community Med Public Health 2016;3:2070-7. 